\title{
Soil Site Suitability Evaluation of Crops for Dorika Watershed of Assam
}

\author{
Arunima Gogoi ${ }^{*}$, M.C. Talukdar², A. Basumatary ${ }^{2}$, U. Baruah ${ }^{3}$ and J. Deka ${ }^{2}$ \\ ${ }^{1}$ Citrus Research Station, Assam Agricultural University, Tinsukia-786125, Assam, India \\ ${ }^{2}$ Department of Soil Science, Assam Agricultural University, Jorhat-785013, India \\ ${ }^{3}$ Regional centre NBSS \& LUP (ICAR), Jorhat, India \\ *Corresponding author
}

\begin{tabular}{|l|}
\hline K e y w o r d s \\
$\begin{array}{l}\text { Soil site suitability } \\
\text { evaluation, }\end{array}$ \\
$\begin{array}{l}\text { Watershed, Water } \\
\text { harvesting structure }\end{array}$ \\
\hline Article Info \\
\hline $\begin{array}{l}\text { Accepted: } \\
\text { 24 September } 2018 \\
\text { Available Online: } \\
\text { 10 October } 2018\end{array}$ \\
\hline
\end{tabular}

A B S T R A C T
The present study was undertaken to prepare land use plan for Dorika watershed of Sivasagar District in Assam based on soil site suitability evaluation of crops. The area coverage of this watershed comprises between $26^{\circ} 48^{\prime}$ to $27^{\circ} 03^{\prime} \mathrm{N}$ latitude and $94^{\circ} 27^{\prime}$ to $94^{0} 52^{\prime} \mathrm{E}$ longitude. The watershed boundaries were delineated based on Survey of India toposheet $(1: 50,000)$ no. 83J/13, 83J/9, 83I/12 and I/8 and. R2 L4 MX Remote sensing data. Generally, the soils under this watershed were found to be strongly acidic, high organic carbon content, low in CEC, medium to high base saturation and texture varies from coarse to fine texture. Soil $\mathrm{pH}$, Drainage and nutrient constraints were the limiting factors for potential utilization of the land resources. Soil site suitability of crops was evaluated for crops such as rice, mustard, potato, tea etc. Several crops are recommended depending on their suitability for the post rainy season in the soils which are kept fallow in the present land use system. Rice is the main crop under this watershed and cultivated during the rainy season due to imperfect drainage though the soils are moderately and marginally suitable. In present study, it was observed that low precipitation in early crop growth stage or growing cycle during rabi crops is one of the major constraints. To deal with such situations or dry spells, for cultivation of rabi crops, it becomes necessary to harvest rainwater in water harvesting structures for life saving or supplementary irrigation. So, harvesting or storing of rainwater appears to be an alternative proposition. Results of this study revealed that the study area under rice fallow cropping system could be modified into double cropping system with the use of proper fertility management and life saving irrigation.

\section{Introduction}

Sivasagar district of Assam occupies an area of 2, 66,800 ha constituting 3.40 per cent of the states geographical area (Dutta, 2009). Dorika is one of the major rivers in Sivasagar district. Dorika watershed covers an area of 27,352.5 ha. The watershed atlas code of
Dorika watershed is 3B3D1 (All India Soil and Land Use Survey, 1990). The river Dorika originates from the foothills areas of Assam bordering Nagaland flows though Sivsagar district and merge into the river Dikhou near Brahmaputra. Finally, falls in to the river Brahmaputra. More than 90 per cent people of the watershed are dependent on agriculture but 
have erratic land use due to poor management of soil as a whole that necessitates the study for scientific land use planning. Therefore, proper land use planning on the basis of land evaluation is of paramount importance for rational utilization of land resources. This watershed has a niche of different physiographic units and the soils have different inherent characteristics. Most of the cultivated areas under this watershed remain inundated for most part of the rainy season.

Rice is cultivated during the rainy season and thereafter most of the cultivable lands remain fallow. A critical appraisal of land resources and then allocating them to the various cropping system in both rainy and post rainy seasons based on their potential will improve the cropping intensity and compensate the crop loss suffered during rains and floods (Vadivelu et al., 2003). In such attempts the soil maps prepared with sufficient ground truth play a vital role in fitting the site specific cultivation. Therefore, the present investigation was taken up to evaluate the soils of Dorika watershed for growing various crops, particularly introducing cultivation of some important crops during rabi season in the dominantly rice alone cropping system and to provide scope for water harvesting in Dorika watershed using GIS and Remote Sensing Technique.

\section{Materials and Methods}

The information pertaining to the study area as well as the materials and methods utilized in the present investigation is described under the following heads.

\section{Site description}

The Dorika watershed of Sivasagar district is a part of the Upper Brahmaputra Valley Zone of Assam. This watershed has an area of 273.525 sq $\mathrm{km}(27,352.5 \mathrm{ha})$ comprising topography of hill to alluvial plain. The drainage network of this watershed comprises Namsai Nai, Taola jan, Dorika River, Chataijan, Nimaijan, Nimonagarh, Timuk Nai and Dillih Nai.

The watershed area represents the plains of the Brahmaputra valley. The alluvium deposited at the foothill slopes forming the piedmonts. Geology of the area is alluvium of Pleistocene (Wadia, 1966) and recent periods in the plains and tertiary sedimentary rocks in the hill. The soil moisture of this study area is Udic. and hyperthermic regime.

The northern part of this watershed particularly along the river Brahmaputra is often subjected to flooding during the rainy season. A major part of the watershed is often remaining under inundation for the most part of the rainy season. The drainage condition is poor during and immediately after flooding.

\section{Climate}

The climate of this area is humid subtropical with an average annual rainfall of 2,334 $\mathrm{mm}$. The soil moisture of this study area is Udic and the soil temperature regime is hyperthermic.

\section{Collection of soil samples and laboratory analysis}

Nine profile (depth wise) samples representing different physiographic units were selected and horizon wise soil samples were collected from each of the selected pedon. Morphological features of each pedon were described with standard procedure (All India Soil and Land Use Survey Organization, 1971).

Morphological features of each pedon were studied in the field following standard procedure (All India Soil and Land Use Survey Organization, 1971). The standard 
methods were adopted for physico-chemical analysis of soil.

Soil classification was carried out on the basis of morphological and physico-chemical properties of soils, following 'Keys to Soil Taxonomy’ (Soil Survey Staff, 2006).

\section{Delineation of Dorika watershed}

The boundary of Dorika watershed was delineated based on Survey of India toposheet No. No. 83J/13, J/9 and 83I/12 on 1:50,000 scale and IRS, Resources at- 2 L4 FX remote sensing data (1:50,000 scale).

\section{Results and Discussion}

Digital data of IRS, R-2 L4FX data of November and December, 2011 with a spatial resolution of $5.8 \mathrm{~m}$ was used and geocoded using TNT mip (Map image processing) software with reference to toposheet. Geocoded FCC was visually interpreted and in conjunction with survey of India toposheet No. $83 \mathrm{~J} / 13, \mathrm{~J} / 9$ and $83 \mathrm{I} / 12$ on $(1: 50,000$ scale). Remote sensing data (Resources at- 2, L4 FX) were geo referenced and digitized to delineate the watershed boundary based on drainage network, water flow path and ground truth verification. Digital Elevation Model (DEM) map was also used to see the water flow path. Finally watershed boundary area was extracted from the imagery with the help of GIS tools (Fig. 1 and 2).

\section{Preparation of physiographic map}

Physiographic map of Dorika watershed was prepared based on Survey of India toposheet No. 83J/13, J/9 and 83I/12 (1:50,000 scale) in conjunction with IRS Resources at- 2, L4 FX data. The Remote sensing data were geo referenced and digitized to prepare the physiographic map. Visual and digital interpretation was used to delineate the watershed boundary and physiographic units within the boundary. Results were validated based on ground truth. Four distinct physiographic units were identified within the watershed boundary, which includes alluvial plain, recent flood plain, piedmont plain and hill (Fig. 2). Alluvial plain appeared light green in colour with coarse texture and nonlinear pattern. It was found that $193 \mathrm{sq} \mathrm{km}$ area was occupied by alluvial plain and $44 \mathrm{sq}$ $\mathrm{km}$ area occupied by recent flood plain. About $31 \mathrm{sq} \mathrm{km}$ area was occupied by piedmont plain. Fine texture with dark uniform red to medium red tone indicated hills in the image. Another $4.97 \mathrm{sq} \mathrm{km}$ area was found to be under hills.

\section{Soils}

Four distinct physiographic units were recognized in the studied area which included alluvial plain, recent flood plain, piedmont plain and hill soils. Nine soil site locations were identified under this watershed representing each physiographic unit. Alluvial plain soil (Gormur, P2; Rajabari, P3; Moran gaon, P4; Luthurichetia gaon, P5 and Banmukh, P7). The texture of the soils varies from sandy loam to clay loam or silty clay to clay in texture. The soils of Recent flood plain soil (Dorikaghat, P6; Chutia gaon, P8; Mogona gaon, Panbecha P9) which situated in northern side of river Dorika are silty loam in texture. Whereas the soils of Santak are the south eastern part of this watershed lies near the Naga hills and texture varies from sandy loam to loamy sand. Generally, the soils under this watershed were found to be strongly acidic, high organic carbon content, low in CEC, medium to high base saturation and texture varies from coarse to fine texture. The pedons (P1, P2, P3, P4, P5, P6, P7 and P9) of Dorika watershed were classified as Inceptisols. The temperature regime of this soil was hyperthermic and pedon P1, P2, P3, P4, P6, P7 and P9 qualified for udic soil 
moisture regime. So these soils were classified as Udepts as suborder level. These soils qualified Dystrudepts at great group level. The soils of P8 (Chutia gaon) belonged to Entisols as these soils did not have any diagnostic horizon other than ochric. These soils were saturated with water during some parts of the year and had low chroma low chroma (1-2) accompanied by mottles. These soils were classified as Aquents suborder and Endoaquents at great group level. Further, the soil represented the central concept of subgroup. So, these soils were placed in Typic Endoaquents at subgroup level.

\section{Soil site suitability evaluation of crops}

The suitability of the soils for growing rice, wheat, maize, mustard, potato, banana and tea was evaluated by Sys method (Sys et. al., 1991). The soil characteristics were matched with the requirements of the crops at different limitation levels. The suitability classes and subclasses were decided by most limiting soil characteristics. After the evaluation, the soil units comprising two or more soil series were allotted to these crops for which they are highly suitable (S1) and moderately suitable (S2). The crops which were in association with marginally suitable (S3) and presently not suitable (N1) classes are not recommended because their cultivation will not be economical. Thus, the site specific cropping plan was prepared for identified location of Dorika watershed based on soil characteristics and limitation of soil site suitability.

Soil site suitability evaluation for major crops

\section{Cereals}

\section{Winter rice (Sali)}

As per Sys's (Sys et al., 1993) soil site suitability assessment revealed that soils of piedmont plain soils were not suitable (N2), alluvial plain soils were marginally suitable (S3) and recent flood plain soils (S2) were moderately suitable for winter rice cultivation (Table 1). The soils of Santak (piedmont plain), Gormur and Rajabari (alluvial plain) were found to be unsuitable for winter rice cultivation due to limitation of wetness parameters like flooding and drainage. Among Sys parameters, flooding and drainage were found to be the major constraints controlling the suitability class. But, in kharif season, rice is the major crop cultivated in all soils of the study area. In Assam, more than 80 per cent of annual rainfall used to receive during this period which coincides with winter rice and that reflects the average yield efficiency percentage (AYEP) of winter rice. The landscape of piedmont plain and alluvial plain soil does not favour flooding and all the rice cultivated soils used to remain saturated due to continuous rainfall. Hence, no flooding and drainage could not consider as major constraints. In addition, winter rice showed that the average yield efficiency percentage (AYEP) of 169.81 for piedmont plain, 205.65 for alluvial plain and 184.76 per cent for recent flood plain. Winter rice was found to be climatically highly suitable for the study area. So, the soils of Dorika watershed could be modified into moderately suitable (S2) to marginally suitable (S3) in alluvial plain and marginally suitable (S3) in piedmont plain soil. In the study area, it was also observed that the alluvial plain soils were more suitable for rice crop than the recent flood plain followed by the piedmont plain soil. Yield losses were observed in recent flood plain area due to flooding which contribute lower yield in recent flood plain as compared to alluvial plain soil.

\section{Autumn rice (Ahu rice)}

Suitability evaluation for autumn rice (Ahu rice) by Sys et al., (1993) method revealed 
that the all soils under this watershed were marginally suitable for (S3) ahu rice cultivation (Table 1) due to limitation of precipitation in early period of crop growth. Beside this, textural limitation, low $\mathrm{pH}$ and unsuitable drainage condition was found as limiting factor for ahu rice cultivation.

As per Sys et al., (1993), low organic carbon content was found as one of the major constraints. Moreover, AYEP of autumn rice was almost twice (210.79) than that of state average indicating better adaptability of autumn rice in that area. Considering, all these and application of irrigation water, Sys's suitability class for autumn rice could be modified to moderately suitable in alluvial plain and recent flood plain soil. Piedmont plain soil remained as same as mentioned by Sys's suitability evaluation because of textural limitation.

\section{Wheat}

According to Sys's suitability evaluation for wheat crop revealed that the whole area was unsuitable (N2) for growing of the crop due to low precipitation during early crop growth (Table 1). However, unprecedented rainfall during the month of March and April coinciding for wheat maturity was a serious limitation in this study area. Selection of short duration variety might encounter such situation.

Hence, the suitability classes were slightly modified to presently not suitable (N1) for all site of location under the study area. Low precipitation during growing cycle, soil acidity, and texture were found to be key limitations for growing wheat crop in these areas. Similar findings were also reported by Borah (2006) in Kamalabari area of Assam and Baruah (2003), Vadivelu et al., (2004a) and Dutta (2009) for some soils of the Brahmaputra valley.

\section{Rabi Maize}

As per Sys's soil site suitability assessment revealed that rabi Maize was unsuitable (N2) for cultivation due to low precipitation during growing cycle.

\section{Oilseeds}

\section{Rapeseed mustard}

As per Sys's soil site suitability evaluation revealed that the study area was not suitable (N2) for rapeseed/mustard due to low precipitation, high relative humidity, texture poor drainage and low $\mathrm{pH}$ content (Table 1).

But considering average yield efficiency percentage (AYEP) of rapeseed mustard all these Sys's suitability classes were modified to moderately suitable (S2) for all three physiographic unit except the soils of Rajabari (alluvial plain) and Panbecha (recent flood plain).

\section{Vegetables}

\section{Potato}

Soil suitability assessment for Potato of the study area was found to be unsuitable (N2) (Table 1). According to Sys limitation, low precipitation is the major constraints for cultivation of potato.

Texture and organic carbon content also act as a one of major limiting factor for cultivation of potato. In the study area, low precipitation, could not affect the crop severely as high relative humidity and dew could sustain the water for some periods only.

So, Sys suitability class for potato of piedmont plain was modified to highly suitable (S1) considering texture, organic carbon content, and good irrigation facility. 


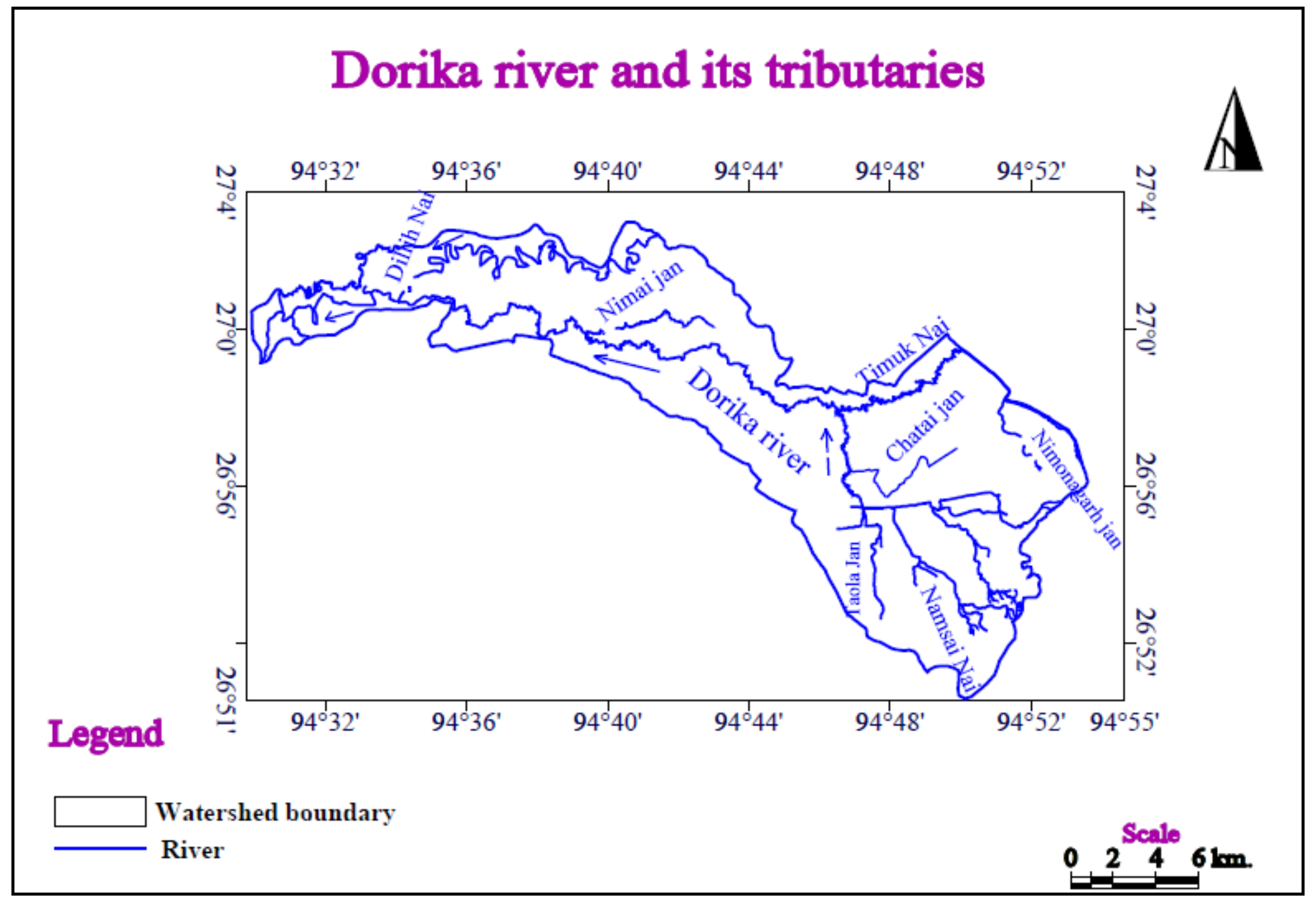


Fig.2 Physiographic map of Dorika watershed

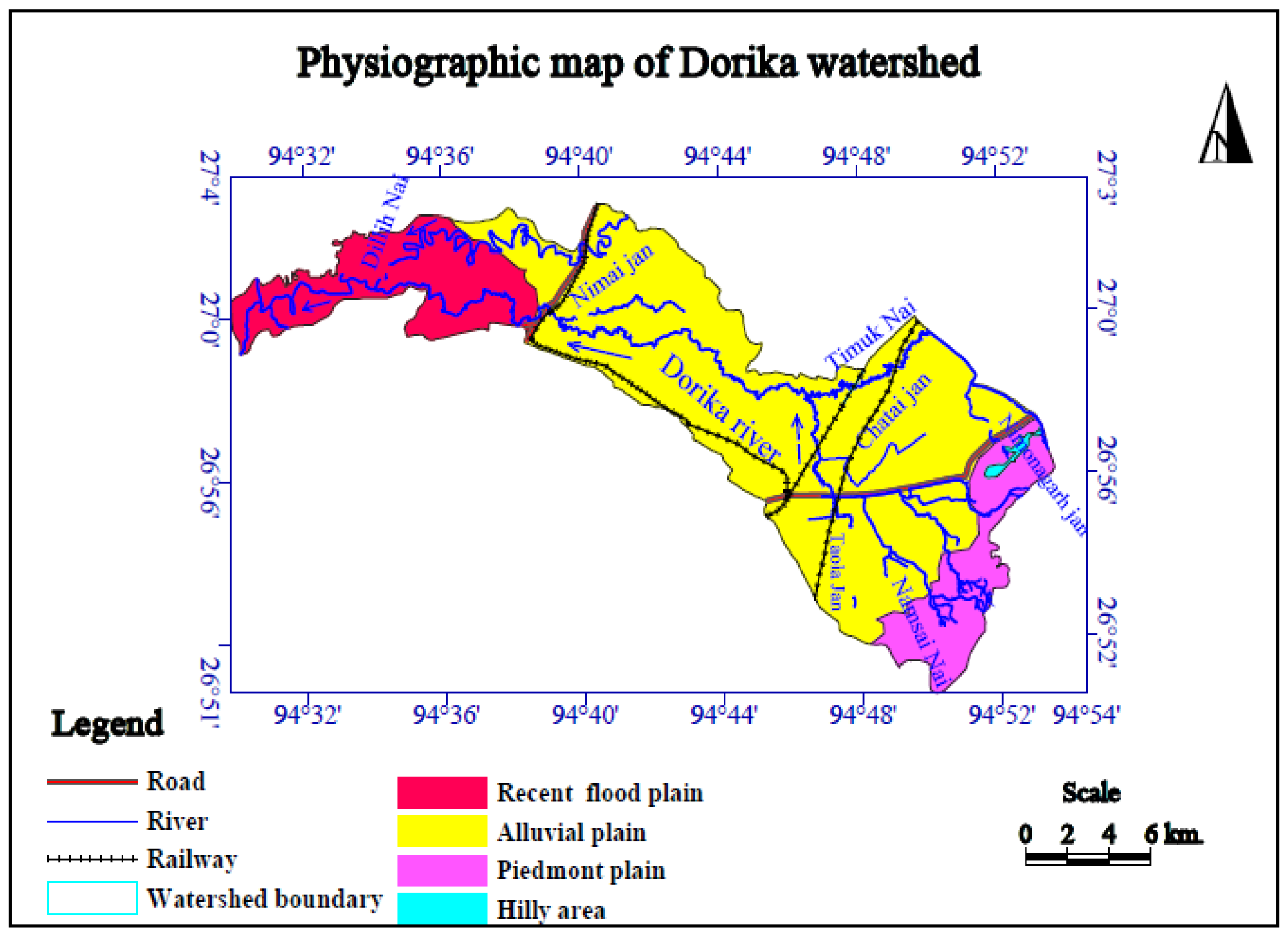


Table.1 Suitability evaluation of Dorika watershed

\begin{tabular}{|c|c|c|c|c|c|c|c|c|c|c|c|c|}
\hline Location No. & $\begin{array}{l}\text { Sali } \\
\text { rice }\end{array}$ & Ahu rice & Wheat & Maize & Potato & Cabbage & Pea & Tomato & $\begin{array}{l}\text { Rapeseed/ } \\
\text { mustard }\end{array}$ & Tea & Sugarcane & Banana \\
\hline \multicolumn{13}{|l|}{ Piedmont plain } \\
\hline P1(Santak) & S3wsf & $\mathrm{S3} c w s f$ & $\mathrm{~N} 1 c s f$ & $\mathrm{S3} c s f$ & $\mathrm{~S} 1 \boldsymbol{c f}$ & $\mathbf{S} 2 c f$ & S1cfs & S3 cfs & $\mathbf{S} 2 \boldsymbol{c f}$ & S1sf & $\mathrm{S} 2 \mathrm{cfs}$ & S3fsc \\
\hline \multicolumn{13}{|l|}{ Alluvial plain } \\
\hline P2(Gormur) & S3wfs & $\mathrm{S} 2 c w s f$ & N1 csf & S3cf & $\mathrm{S} 1 \boldsymbol{c f}$ & $\mathbf{S} 2 c f$ & $\mathbf{S} 2 c f$ & S2cf & $\mathrm{S} 2 c f s$ & $\mathrm{~S} 2 c w f$ & S3cws & $\mathrm{S} 2 \mathrm{fwc}$ \\
\hline P3(Rajabari) & S3wfs & $\mathrm{S} 2 c w s f$ & $\mathrm{~N} 1 c s f$ & S3 csf & S3 $c f s$ & $\mathrm{~S} 3 c s f$ & $\mathrm{~S} 2 c f$ & $\mathrm{~S} 2 c f s$ & $\mathrm{S3} c f s$ & S2 cwfs & S3 cws & $\mathrm{S} 2 f w c$ \\
\hline P4(Moran gaon) & S2wfs & $\mathrm{S} 2 \mathrm{cwsf}$ & $\mathrm{N} 1 c s f$ & $\mathrm{~N} 1 c f$ & $\mathrm{~S} 2 \boldsymbol{c f}$ & $\mathrm{S} 2 \boldsymbol{c f}$ & $\mathbf{S 3} c f$ & $\mathbf{S} 2 \boldsymbol{c f}$ & $\mathrm{S} 2 c f s$ & $\mathrm{~S} 3 c w f$ & S3cws & $\mathrm{S} 3 f w c$ \\
\hline P5(Luthurichetia gaon) & S2wfs & $\mathrm{S} 2 c w s f$ & $\mathrm{~N} 1 c s f$ & $\mathrm{~S} 3 \boldsymbol{c f}$ & $\mathrm{S} 2 \boldsymbol{c f}$ & $\mathrm{S} 2 c f$ & $\mathrm{~S} 3 \boldsymbol{c f}$ & $\mathrm{S} 2 c f$ & $\mathrm{~S} 2 c f s$ & $\mathrm{~S} 3 c w f$ & S3cws & S3 fwc \\
\hline P7 (Banmukh) & $\mathrm{S} 2 w f s$ & $\mathrm{~S} 2 \mathrm{cwsf}$ & $\mathrm{N} 1 \mathrm{csf}$ & $\mathrm{S} 3 c f$ & $\mathrm{~S} 1 \boldsymbol{c f}$ & $\mathrm{S} 3 c f$ & $\mathrm{~S} 2 \boldsymbol{c f}$ & $\mathbf{S} 2 c f$ & $\mathrm{~S} 2 c f s$ & $\mathrm{~S} 3 \boldsymbol{c w f}$ & S3cws & $\mathrm{S3} f w c$ \\
\hline \multicolumn{13}{|l|}{ Recent flood plain } \\
\hline P6(Dorikaghat) & $\mathrm{S} 2 w f s$ & $\mathrm{~S} 2 \mathrm{cwsf}$ & $\mathrm{N} 1 c w s f$ & S3 cwf & $\mathrm{S} 1 c w f$ & $\mathrm{~S} 3 c f$ & $\mathrm{~S} 2 c f$ & $\mathrm{~S} 2 \boldsymbol{c f}$ & $\mathrm{S} 2 c f$ & N1 $f w$ & N1 cws & $\mathrm{N} 1 f w c$ \\
\hline P8(Chutia gaon) & S2wfs & $\mathrm{S} 2 c w s f$ & N1cwsf & S3 cwf & $\mathrm{S} 2 c w f$ & $\mathrm{~S} 3 c f$ & S3cf & $\mathrm{S} 2 c f$ & $\mathrm{~S} 2 c f$ & N1 $f w$ & N1 cws & $\mathrm{N} 1 f w c$ \\
\hline P9(Panbecha) & $\mathrm{S} 2 w f s$ & $\mathrm{~S} 2 c w s f$ & N1cwsf & $\mathrm{S3} c w f$ & $\mathrm{S3} c w f s$ & $\mathrm{~S} 3 c f$ & S3cf & $\mathrm{S} 2 c f$ & $\mathrm{S3} c f s$ & N1wfs & N1 cws & $\mathrm{N} 1 f w c$ \\
\hline
\end{tabular}

Table.2 Preparation of site specific action plan

\begin{tabular}{|c|c|c|c|c|}
\hline Location No. & $\begin{array}{c}\text { Autumn } \\
\text { (February-June) }\end{array}$ & $\begin{array}{c}\text { Winter } \\
\text { (July-November) }\end{array}$ & Summer (November- March) & $\begin{array}{l}\text { Year round plantation/ } \\
\text { horticultural crops }\end{array}$ \\
\hline \multicolumn{5}{|c|}{ Piedmont plain } \\
\hline P1(Santak) & - & Sali rice & Potato/Cabbage/ Maize & Tea/Sugarcane \\
\hline \multicolumn{5}{|c|}{ Alluvial plain } \\
\hline P2(Gormur) & Ahu rice & Sali rice & Potato/Rapeseed /Mustard/Pea/Cabbage/Tomato & Tea/banana \\
\hline P3(Rajabari) & Ahu rice & Sali rice & Pea/tomato/maize & Tea/banana \\
\hline P4(Moran gaon) & Ahu rice & Sali rice & Potato/Rapeseed /Mustard /Cabbage/Tomato & - \\
\hline P5(Luthurichetia gaon) & Ahu rice & Sali rice & Potato/Rapeseed /Mustard/ Cabbage/Tomato & - \\
\hline P7(Banmukh) & Ahu rice & Sali rice & Potato/Rapeseed /Mustard/Pea/ Tomato/Maize & - \\
\hline \multicolumn{5}{|c|}{ Recent flood plain } \\
\hline P6(Dorikaghat) & Ahu rice & Sali rice & Potato/Rapeseed /Mustard/Pea/ Tomato & - \\
\hline P8(Chutia gaon) & Ahu rice & Sali rice & Potato/Rapeseed /Mustard/Pea/ Tomato & - \\
\hline P9(Mogona gaon, Panbecha) & Ahu rice & Sali rice & Tomato & - \\
\hline
\end{tabular}




\section{Tomato}

Suitability evaluation for tomato as per Sys et al., (1993) revealed that the study area were unsuitable (N2) due to low precipitation during growing cycle (Table 1). Low precipitation in early crop growth stage, $\mathrm{pH}$ and Organic carbon is the major constraints that can limit the cultivation of Tomato. By application of lime and organic manure, the suitability class of alluvial plain and recent flood plain could be modified to moderately suitable (S2). Due to textural limitation the piedmont plain soil could be remained as marginally suitable (S3).

\section{Cabbage}

Soil site suitability assessment revealed that Cabbage was not suitable (N2) in all physiographic condition due to the constraints of low precipitation in growing cycle and low $\mathrm{pH}$ of the soils of watershed (Table 1) by application of life saving irrigation, and lime the crop could be modified into highly suitable (S1) in piedmont plain soil and moderately suitable (S2) in alluvial plain (Gormur, Moran gaon, Luthurichetia gaon and Banmukh) and marginally suitable in recent flood plain (Dorikaghat, Chutiagaon and Panbecha). In Rajabari soil of alluvial plain also remained as marginally suitable (S3) due to presence of clay texture.

\section{Pea}

As per Sys's suitability assessment for growing pea was not suitable (N2) due to low precipitation during crop growing cycle in this study area (Table 1). But in study area low precipitation could not hamper the cultivation of those crops rather it was beneficial. $\mathrm{pH}$ was found to be one of the major constraints for cultivation of pea. Well drained soils with high organic matter content allow better root aeration and thereby less disease attack like root rot. High acidity is not tolerated and liming may be required below $\mathrm{pH}$ 5.5. Application of life saving irrigation, suitability of pea could be modified to highly suitable in the soils of Rajabari (alluvial plain) and moderately suitable to marginally suitable (S3) for other soils of alluvial plain, recent flood plain and piedmont plain soil with consideration of texture, NPK status and organic carbon.

\section{Plantation crop}

\section{Tea}

As per Sys's suitability assessment for cultivation of tea revealed that the piedmont plain soil (P1) was found to be marginally suitable (S3) and limitation approach showed that the alluvial plain soils were moderately suitable (S2) to marginally suitable (S3). The climate was found to be highly suitable (S1) for tea as per Sys's soil site suitability criteria (Table 1). Due to flooding in recent flood plain area with soil limitations of organic carbon, flooding, and poor drainage condition the soils of recent flood plain area was not suitable (N2) for tea cultivation. It was observed that the soils of Santak (piedmont plain) are presently under tea cultivation. It was reported that light texture soil like sandy loam or loamy soil was the best texture for tea cultivation. So, considering textural suitability with application of organic manure, the soils of piedmont plain soil (Santak) could be modified to highly suitable. The alluvial soils (Gormur and Rajabari) could be categorised as moderately suitable and remaining others (Moran gaon, Luthurichetia gaon and Banmukh) were marginally suitable (S3) for tea cultivation. Recent flood plain area could be remained as presently not suitable (N1) for tea cultivation due to flooding. Soil fertility and poor drainage were found to be the most limiting factors in the studied area. By improving fertility status and drainage most 
of the studied soils of alluvial plain could be upgraded to moderately suitable (S2) to highly suitable (S1) class.

\section{Banana}

Soil site suitability for horticultural crops was also evaluated as per Sys' method. Banana is moderately suitable (S2) in alluvial plain soil of Gormur and Rajabari.

\section{Sugarcane}

According to Sys suitability evaluation, the climatic suitability is not suitable for sugarcane, hence it was found to be unsuitable (N2) for all three physiographic units for sugarcane cultivation (Table 1). But considering other parameters of soil, the suitability of sugarcane in piedmont plain soil could be modified to moderately suitable (S2). Considering, textural suitability, alluvial plain soil was categorized into marginally suitable (S3). Recently flood plain area could be remained as presently not suitable (N1) due to occurrence of flooding. By application of management practices like irrigation, improving drainage condition and fertility status, the suitability of sugarcane could be improved.

\section{Major constraints}

The major constraints of the watershed lie in the physical properties (texture), poor drainage, low precipitation during early crop growth stage or growing cycle of rabi crops, acidity and fertility. The acidity and fertility limitation could be improved by using appropriate amendments like lime, organic manure and green manure etc. Most soils of recent flood plain and piedmont plain, owing to light textured could be exploited for atleast two crops during rabi and post rabi seasons. Low precipitation during early crop growth stages or growing cycle of rabi crops could be addressed increasing soil moisture status either by following moisture conservation technique or through supplementary irrigation.

\section{Land use plan}

Based on soil site suitability of crops, socio economic conditions, length of growing crop period, occurrence of flood, net return and major constraints of the study area few land use plan for different physiographic units were suggested. It is expected that implementation of land use plan would enhance the existing productivity of the study areas. On the basis soil site suitability criteria and limitation (Table 1) site specific cropping plan was prepared for different seasons (Table 2). Various cropping system like ahu rice- sali rice-rapeseed/mustard, ahu rice- sali rice-rabi vegetables can be adopted in study area. The areas not found suitable for growing any crops can be utilized for other livelihood options.

The area experiences sufficient rainfall with length of growing period of 290 days and optimum temperatures suitable for a number of crops. But, $\mathrm{pH}$, drainage, physical texture, nutrient constraints become the limiting factors for potential utilization of the land resources. Some agricultural crops like potato, mustard, maize, pea, green gram, French bean can be grown in these soils with liming and fertilizer management.

Beside this, the water stored in the soils is in appreciable amount which can be utilized for intensification during Rabi under rainfed condition. The water stored in the water harvesting structure can be utilized for life saving irrigation during critical periods particularly for growing wheat and potato. Results of this study revealed that the study area under rice fallow cropping system could be modified into double cropping system with 
the use of proper fertility management and life saving irrigation.

\section{Acknowledgements}

The authors are thankful to the Assam Agricultural University, Jorhat for providing research facilities to carry out the experiment.

\section{References}

All India Soil and Land Use Survey (1990). Watershed Atlas of India (on 1:1 million scale).

All India Soil and Land Use Survey Organization (1971). Soil Survey Manual, IARI, New Delhi.

Anonymous (2012). Profile of Agri-Horti sector of Assam. Land Utilization Statistics, Directorate of Economics and Statistics in Assam. www.agriassam.in/ agri Horti_profile/Profile_of Agri Horti sector_of Assam_June 2012' pdf.

Deka, Bipul; Baruah, T.C.; Dutta, Marami and Karmakar, R.M. (2009). Landscape Soil Relationship and Pedogenic Evaluation of Soils in Ghiladhari Watershed of the Brahmaputra valley of Assam. J. Indian Soc. Soil Sci. 57(3): 245-252

Dutta, Marami (2009). Land use planning of Tipukjan watershed of Sivasagar district using GIS and remote sensing technique. Ph.D. Thesis, AAU, Jorhat

Jenny, H. (1931). Behaviour of potassium and sodium during the process of soil formation. University of Missouri
Agricultural Experimental Station Research Bulletin, pp. 162.

McCloy, K.R. (1995). Resource management information system, processes and practice, Taylor and Francis, U.K.

Sarkar, D.; Baruah, U.; Gangopadhyay, S.K.; Sahoo, A.K. and Velayutham, M. (2002). Charactrisation and classification of soils of Loktak catchment area of Manipur for sustainable land use planning. J. Indian Soc. Soil Sci. 50: 196-204.

Sen, T.K.; Dubey, P.N.; Nayak, D.C.; Baruah, U.; Bhattacharyya, T.; Maji, A.K. and Velayuthum (2003). Soil resource information for agricultural planning and development of Assam. Agropedology 13: 50-59.

Soil Survey Staff (2006). Keys to Soil Taxonomy. United States Department of Agriculture, Natural Resources Conservation Service. Washington, D.C.

Sys, C. Van Ranst, E. and Debaveye, J. 1991. Land Evaluation, Part II, Methods in Land Evaluation. Agricultural Publication No.7, General Administration for Development Cooperation, Belgium.

Vadivelu, S., Baruah, U., Bhaskar, B.P. Thampi, J. Sarkar, D. Walia, C.S. Nayak, D.C. and Maji A.K. 2003. A land use plan for Jorhat district of Assam State. Agropedology, 13: 1-10

Wadia, D.N. (1966). Geology of India. The English Language Book Society and MacMillan Co. Ltd., London, pp. 76-92.

\section{How to cite this article:}

Arunima Gogoi, M.C. Talukdar, A. Basumatary, U. Baruah and Deka, J. 2018. Soil Site Suitability Evaluation of Crops for Dorika Watershed of Assam. Int.J.Curr.Microbiol.App.Sci. 7(10): 3214-3224. doi: https://doi.org/10.20546/ijcmas.2018.710.373 